\title{
The Promotion of Adult's Health from Childhood. Practical Training
}

\author{
Francisco Nunez Gomez* \\ Department of Pediatrics, Obstetrics and Gynecology, University of Valencia, Spain
}

Submission: October 17, 2016; Published: October 27, 2016

*Corresponding author: Francisco Nunez Gomez, Department of Pediatrics, Obstetrics and Gynecology, University of Valencia, Hospital Clinico Universitario de Valencia, Spain

\section{Perspective}

The practical training to the students of school teacher is designed to serve to rein force the contents of the theoreticallessonsemphasizing the importance of respecting the timing of child'sgeneral and languageinterests. We consider necessary this clarification as our intervention in the training future. Teachers is limited to those who are going to teach children before six years old (infant school). The primary and secondary schooling remains outside, for the moment, in our scope.

Its content is focused mainly for the child to acquire practical skills and strengthen their interests and attitudes in the problems of health and its prevention in the own childhood and adulthood. Some important aspects for the prevention of the diseases of civilization that have been included in the theoreticaltalks are beyondpracticalconsideration because its inclusion would be out of context. We refer to such important issues as the toxic habits (smoking, alcohol, consumption of illegaldrugs, etc.,). Weemphasize the content more directly related to healthy nutrition, physical exercise, and the personal hygiene of the child. The practical aspects of the subject include two kinds of activities according to the permanence of the teacher during its development [1-7].

Practical classroom teaching. It is composed of three types of activities

a. Activities upon completion of the theoretical exposition of each lesson. They are intended to strengthen the contents explained by examples of common knowledge as well as the teacher can take advantage of immediate reality. During the last halfhour of the class are exposed topics-related activities. For example, students are asked that they value on the issue of school canteens, a school menu for children of a certain age, calculating calories provided by composition tables of foods, caloric distribution, and by using different food according to the Food Pyramid. For the realization of these works, they must attend web resources listed to the students.

b. Practices of basic cardio pulmonary resuscitation (CPR). Its purposeis to train future teachers in the application of first aid in case of accidents and urgent severe episodes. Workshops of CPR last two hours where students must complete basic activities of PCR using puppets. Professor trains students on value pulses, effort and respiratory rate and cardiac massage.

c. Seminars and workshops during the weeks of follow-up. Throughout the four months period of the course there are two free weeks from regular education. These general gaps of the teaching periods facilitates the revision of the whole matter given up to the moment as well as the articulation with other related materials. Held seminars on nutritional topics. The workshops aim to that future teachers are acquainted with practical issues that later must teach their students. For example, a workshop reviews the information provided by the food containers and assess whether this is correct. Students will go to super markets to examine the exposed foods.

\section{Non presential practical teaching}

a. Work Groups: They are activities aimed to promoting the personal initiative andwork as a team. They are the mostcontroversial issues as didactic tasks could providemany diverse developments. Students are distributed into groups of ten, and a project of the matter is assigned to each of them. The work may consist of the elaboration of a set of elements that integrate contents and teaching methodology of any child's play or the preparation of explanatory posters on any aspect of the issue. Studentsmaterials must holdboth drawings and texts.

\section{Limitations}

The teaching of this subject faces several difficulties. In particular, the fact that this subject is taught during the first 
academic year, when students' educational level is still rather limited, restrains students from thoroughly understanding the crucial importance of improving health during childhood and the eventual consequences in adulthood

\section{References}

1. Beard R (1974) Pedagogia y Didactica de la Ensenanza Universitaria. Oikos-Tau, S.A., Barcelona.

2. Higuet G (1956) El arte de ensenar. Paidos, Buenos Aires.

3. Krathwohl DR, Bloom BS, Masia BB (1964) Taxonomy of Educational Objectives. Handbook II: Affective Domain, Mc Kay Co. Inc., NewYork, USA.
4. Mager RF (1971) Comment definir des objectifs pedagogiques. Gauthier Villars, Paris, France.

5. OMS (1957) Los accidentes de la infancia: la observacion de los hechoscomo fundamento de las medidas prevent ivas, Ser. Inf. Tecn. 118, Ginebra.

6. OMS (1976) Guide Pedagogique. Geneve, Switzerland.

7. Thomsen OB (1973) Formacion de los Profesores de Medicina en Pedagogia, Cronica de la OMS

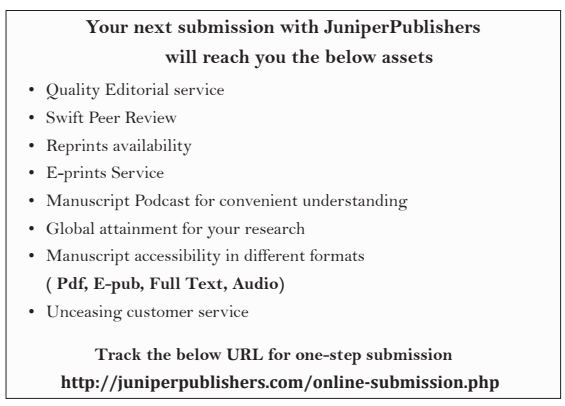

